\title{
WABAH, AGAMA, DAN PUISI
}

\author{
Darmawati M.R. \\ Kantor Bahasa Provinsi Gorontalo \\ Jalan Dokter Zainal Umar Sidiki, Tunggulo, Tilongkabila, \\ Kab. Bone Bolango, Gorontalo \\ darmawatimajid@gmail.com
}

\begin{abstract}
Abstrak
Tahun 2020 mengingatkan kembali keterbatasan manusia ketika berhadapan dengan wabah. Bagaimana puisi mampu merekam peristiwa melalui katakata? Tulisan ini bertujuan mengungkap peristiwa yang dilambangkan katakata dalam puisi Ibrahim Gibra, "Ramadan Kali Ini", melalui analisis semiotik dengan menerapkan teori Riffaterre. Hasil penelitian menunjukkan bahwa puisi "Ramadan Kali Ini" menunjukkan kegelisahan penulis terhadap perpecahan dan keterbelahan yang menimpa orang-orang Islam.

Kata kunci : puisi, semiotik, Riffaterre.
\end{abstract}

\section{Plaque, Religion, and Poetry}

Abstract

The year 2020 reminds us of human limitations when dealing with epidemics. How is poetry able to record events through words? This paper aims to reveal the events symbolized by the words of Ibrahim Gibra's poem, Ramadan Kali Ini by using semiotic analysis by applying the Riffaterre theory. The results showed that this Ramadan Kali Poem shows the writer's anxiety about the divisions that afflict Muslims.

Key words: poetry, semiotic, Riffaterre.

\section{PENDAHULUAN}

Bahasa puisi berbeda dengan bahasa sains (Bujono, 2020). Bahasa sains harus berjalan di tempat. Maknanya dipatok. Presisi dan konsistensi mutlak terjaga. Bagi sains, bahasa tak mampu secara akurat mengindentifikasi pelbagai fenomena alam (Mohamad, 2020:8). Maka, dunia sains membangun sistem lambang matematis beserta konsep yang ketat. Sementara itu, bahasa dalam puisi-terkadang bahasa sehari-hari-menunjukkan paradoksnya: ia terbatas, tetapi juga sebuah aset yang tak tepermanai. Puisi, dalam bentuknya yang ringkas, tetapi padat makna itu, berbicara mengenai sesuatu secara tidak langsung dengan menyembunyikannya ke dalam suatu tanda.
Puisi "Ramadan Kali Ini" dikirim lefo.id (sebuah rubrik sastra di sebuah laman) pada 24 April 2020, tepat pada 1 Ramadan 1441 H, ditulis Ibrahim Gibra.

Puisi itu sederhana, dengan bahasa sehari-hari, ciri khas penyair yang pada akhir 2019 lalu menerbitkan buku kumpulan puisi yang berjudul Karang Menghimpun Bayi Kerapu (Gibra, 2019). Namun, di situlah letak daya gugahnya. "Ramadan Kali Ini” menyoal pula isu agama dan wabah.

Wabah menjadi salah topik yang paling banyak dibahas pada 2020, tak terkecuali dalam bentuk karya sastra, seperti puisi.

Virus korona yang mulai mewabah di Indonesia pada awal Maret 2020 telah membawa perubahan pada berbagai segi kehidupan masyarakat, terutama pada segi 
ekonomi dan sosial. Penjarakan sosial (social distancing) membatasi ruang gerak dan aktivitas sehari-hari, tak terkecuali dalam melaksanakan ibadah. Hal itulah yang menjadi obejk pengamatan dan pendalaman Gibra, lalu dituangkannya ke dalam puisi "Ramadan Kali Ini".

Setiap kali dunia disergap epidemi, puisi selalu menyimpannya dalam kata-kata. Tidak hanya puisi, beberapa novel juga mencatat kengerian manusia menghadapi wabah. Salah satu yang paling dikenal adalah The Plague (Camus, 1948). Novel Albert Camus yang terbit pada 1947 dalam bahasa Perancis (La Peste) itu diterjemahkan menjadi Sampar oleh N.H. Dini. Novel lain yang menceritakan kengerian menghadapi wabah (kebutaan putih) adalah Blindness karya Jose Saramago (Saramago, 1997).

Puisi yang menggambarkan wabah menjadi paling banyak ditulis, baik oleh sastrawan, maupun profesi lain, bahkan masyarakat umum. Hal itu terjadi, barangkali, karena bentuknya yang singkat meskipun dalam bentuknya yang ringkas itu puisi mampu bercerita seluas-luasnya.

Ibnu Al-Wardi, misalnya, merekam banyak catatan tentang sampar yang menimpa Aleppo selama kurang lebih lima belas tahun. Pada 1349 sejarawan Suriah itu menulis puisi tentang wabah sampar yang menghancurkan kota tempat tinggalnya itu sebagai berikut.

I do not scare from Black Death as others

It is but a martyrdom or victory

If I died, I rested from the rivalries

And If I lived, my eye and ear heald (Sneineh, 2020).

Dalam puisinya itu, Al-Wardi mengaku tak banyak yang bisa ia perbuat ketika wabah itu merenggut hampir seribu orang di kotanya setiap hari. Ia mencoba percaya bahwa kalaupun mati karena wabah itu, ia akan bisa beristirahat dari persaingan hidup. Sebaliknya, kalau selamat, hanya mata dan telinganyalah yang pulih. Dua hari setelah menulis puisi itu, Al-Wardi pun kalah oleh keganasan wabah yang menakutkan semua orang itu.

Hal yang sama dilakukan Nazik AlMalaika. Penyair Irak itu juga sempat menulis puisi tentang kolera yang menyerang Mesir pada tahun 1947, sambil menyaksikan prosesi perkabungan yang tak terhitung sejak fajar membuka hari: keretakereta membawa mayat dan keheningan menimpa jalan-jalan di Mesir (Sneineh, 2020).

di mana-mana ada mayat, berduka

tanpa ada pidato bahkan momen untuk keheningan

bahkan penggali kubur telah menyerah muazin mati

siapa lagi yang mendoakan yang mati?

Covid-19 kembali menyepuh ingatan berapa kali manusia harus berhadapan dengan wabah mematikan. Maut hitam, sampar, flu spanyol, dan kolera tiba-tiba hadir berkelebat tanpa diminta. Kematian pun tidak lagi menjadi tragedi, hanya angkaangka statistik yang terus bergerak naik. Di dalam puisi, tragedi seperti itu jauh lebih mencekam.

Lalu, bagaimana Gibra menggambarkan wabah dan agama dalam puisinya? Tulisan ini hendak menjawabnya. Semua peristiwa yang dilambangkan kata-kata dalam puisi Ibrahim Gibra, "Ramadan Kali Ini", akan diungkap dengan menggunakan Semiotik Riffaterre.

Penelitian mengenai analisis semiotik dalam puisi dengan menggunakan teori Riffaterre telah dilakukan oleh Husnul Hatima Adudu dan Dahlia Husain dengan 
judul "Analisis Semiotik dalam Puisi William Blake" (Adudu \& Husain, 2019).

Permasalahan dalam penelitian itu adalah bagaimana mengaplikasikan teori Riffaterre pada puisi William Blake berjudul "The Sick Rose", "My Pretty Rose Tree", dan "The Garden of Love". Metode yang digunakan adalah metode kualitatif deskriptif. Sementara itu, data (catatan tertulis berupa tiga puisi karya William Blake) dikumpulakan dengan teknik membaca log, sebelum dianalisis menggunakan teori Riffaterre.

Berdasarkan analisis, Husnul Hatima Adudu dan Dahlia Husain menyimpulkan bahwa puisi "The Sick Rose" dan "The Garden of Love" menggambarkan kehidupan sebelum Revolusi Prancis terjadi, sedangkan puisi "My Pretty Rose Tree" menggambarkan perasaan pengarang kepada istrinya.

Penelitian sejenis dilakukan oleh Huri, dengan judul "Analisis Semiotik Riffaterre dalam Puisi 'Dongeng Marsinah' karya Sapardi Djoko Damono (Huri et al., 2017). Tahapan analisis dalam penelitian itu adalah (1) pembacaan heuristik dan hermeneutik, (2) tipuan semantik, (3) matriks, model, dan varian, serta (4) hipogram puisi "Dongeng Marsinah". Hasilnya, antara lain, adalah bahwa hipogram puisi "Dongeng Marsinah" yang menunjukkan latar penciptaan puisi berupa cerita tentang kisah Marsinah, seorang buruh pabrik arloji, PT Catur Putra Surya (CPS), di Sidoarjo yang dibunuh pada Mei 1993. Dalam hal ini, hipogram tidak bersumber dari teks atau karya sastra yang lebih dahulu diciptakan, tetapi bersumber dari suatu peristiwa.

Perbedaan penelitian ini dengan kedua penelitian tersebut terletak pada tema puisi yang diangkat. Tema puisi "Ramadan Kali Ini" yang diangkat dalam penelitian ini berkait dengan "peristiwa besar" yang terjadi pada tahun 2020: wabah covid-19.
Banyak puisi yang mengangkat wabah covid-19, tetapi puisi Ibrahim Gibra lain daripada yang lain. "Ramadan Kali Ini" menonjol dengan kritik sosial yang lebih luas dan mengangkat isu agama yang akhirakhir ini banyak dijadikan sumber keterpecahan umat Islam.

Sebelum Gibra, memang telah banyak penyair yang mengangkat persoalan agama dalam larik dan baitnya. Abdul Hadi W.M., misalnya, adalah salah satu penyair yang terkenal dengan puisi-puisinya yang religuis.

Penelitian ini tidak akan membahas sisi kereligiusitasan "Ramadan Kali Ini" (meskipun dari judulnya, puisi itu mengesankan sarat dengan kereligiusan), tetapi akan membahas bagaimana Gibra menyimpan makna di balik tanda-tanda yang digunakannya dalam "Ramadan Kali Ini". Sepintas, Gibra menunjukkan bahwa puisi mampu mengekspresikan keyakinan atau ketidakpercayaan terhadap agama.

\section{TEORI}

Istilah semiotika pada puisi pertama kali dikemukakan Riffaterre dalam tulisannya pada tahun 1974. Tulisan tersebut membawa perubahan besar pada dunia sastra, terutama pada analisis puisi (Riffaterre, 1978).

Semiotika Riffaterre mengemukakan metode pemaknaan yang khusus, yaitu dengan memberi makna karya sastra sebagai sistem tanda atau memproduksi makna tanda-tanda. Riffaterre menjelaskan bahwa puisi merupakan aktivitas bahasa yang berbeda dengan pemakaian bahasa pada umumnya. Akan tetapi, di bagian lain, Riffaterre juga menyatakan bahwa puisi juga menggunakan kata dan struktur bahasa seperti bahasa sehari-hari. Alternatif itu terus berkembang, bolak-balik bergantung pada evolusi selera dan konsep estetik (Riffaterre, 1978:1). 
Menurut Pradopo (1999), semiotika Riffaterre paling tepat dipakai untuk menganalisis sajak disebabkan hasilnya mengarah pada pemberian makna sebuah karya sastra, misalnya puisi.

Ada empat hal yang dikemukakan Riffaterre dalam memproduksi makna puisi, yaitu (1) pembacaan heuristik dan hermeneutik; (2) ketidaklangsungan ekspresi puisi (karya sastra) yang disebabkan oleh penggantian arti (displacing of meaning), penyimpangan arti (distorting of meaning), dan penciptaan arti (creating of meaning); (2) matriks, model, dan varian; dan (4) hipogram (hypogram) atau hubungan intertekstual.

\section{Pembacaan Heuristik dan Pembacaan Hermeneutik}

Pembacaan heuristik disebut juga dengan parafrase, yaitu proses menarasikan puisi. Dalam pembacaan heuristik, sajak dibaca berdasarkan konvensi bahasa atau sistem bahasa sesuai dengan kedudukan bahasa sebagai sistem semiotik tingkat pertama. Sajak dibaca secara linier menurut struktur normatif bahasa. Pembacaan hermeneutik adalah pembacaan ulang dari awal sampai akhir. Pembacaan ini adalah pemberian makna berdasarkan konvensi sastra (puisi).

\section{Ketidaklangsungan Ekspresi}

Menurut Riffaterre (1978), ada tiga hal yang menyebabkan ketidaklangsungan ekspresi, yaitu (a) penggantian arti, (b) penyimpangan arti, dan (c) penciptaan arti.

\section{a. Penggantian Arti}

Penggantian arti terjadi jika suatu kata berarti yang lain, berupa kiasan, atau tidak menurut arti umum. Jenis bentuk kata (kiasan) tersebut, antara lain, adalah
1. metafora: perbandingan secara langsung dalam bentuk yang singkat;

2. simile: perbandingan langsung yang menyatakan sesuatu sama dengan hal yang lain;

3. personifikasi: perbandingan yang menyatakan benda-benda mati atau barang-barang tidak bernyawa seolaholah memiliki sifat-sifat kemanusiaan;

4. metonimia: pertautan yang mempergunakan sebuah kata untuk menyatakan hal lain karena mempunyai pertalian yang sangat dekat; dan

5. sinekdoke: pars pro toto, pertautan yang mempergunakan sebagian dari sesuatu hal untuk menyatakan keseluruhan; dan totem pro parte, pertautan yang mempergunakan keseluruhan untuk menyatakan sebagian (Riffaterre, 1978:2).

b. Penyimpangan Arti

Riffaterre (19780 mengatakan bahwa penyimpangan arti terjadi bila dalam sajak ada

1. ambiguitas, menawarkan penafsiran lain kepada pembaca sesuai dengan asosiasinya;

2. kontradiksi atau ironi, menyampaikan maksud secara berlawanan atau berkebalikan; dan

3. nonsense, menggunakan kata-kata yang secara linguistik tidak mempunyai arti sebab tidak terdapat dalam kosakata.

c. Penciptaan Arti

Riffaterre berpendapat bahwa terjadi penciptaan arti apabila ruang teks (spasi teks) berlaku sebagai prinsip pengorganisasian untuk tanda-tanda keluar dari hal-hal ketatabahasaan yang sesungguhnya secara linguistik tidak ada artinya. Penciptaan arti dapat terlihat dari 
simitri (keseimbangan), rima, enjambemen, dan persamaan posisi (homologues).

Matriks, Model, Varian

Supaya puisi dapat mudah dipahami, dalam konkretisasi puisi, harus dicari matriks atau kata-kata kuncinya. Kata-kata kunci merupakan kata yang menjadi kunci penafsiran sajak yang dikonkretisasikan. Riffaterre menegaskan bahwa puisi dihasilkan dari tranformasi matriks berupa kata, kelompok kata, atau kalimat sederhana menjadi sebuah wacana yang lebih panjang, kompleks, dan nonliteral (Pradopo, 1999). Matriks dapat bersifat hipotesis, yang berati hanya merupakan aktualisasi grmatikal dan leksikal sebuah struktur. Matriks bisa dilambangkan dalam satu kata, tetapi tidak muncul dalam teks. Ia selalu diaktualisasi secara berturut-turut dalam varian-varian yang ditentukan oleh aktualisasi dasar pertama, yakni model.

\section{Hipogram}

Hipogram adalah teks yang menjadi latar penciptaan teks lain atau sajak yang menjadi latar penciptaan sajak lain. Seringkali sebuah sajak baru mendapat makna hakikinya bila dikontraskan (dijajarkan) dengan sajak yang menjadi hipogramnya. Jadi, puisi tidak dapat dilepaskan dari hubungan kesejarahannya dengan puisi sebelumnya. Riffartere (1978) juga menjelaskan bahwa puisi yang diciptakan seorang penyair, tidak lepas dari puisi-puisi atau karya sastra atau peristiwa yang sebelumnya pernah lahir atau dapat pula peristiwa yang menginspirasi penyair menciptakan karyanya.

\section{METODE}

Penelitian ini adalah penelitian kualitatif dengan metode deskriptif. Data berasal dari data tertulis, berupa kata, frasa, klausa atau kalimat dari puisi "Ramadan Kali Ini" karya Ibrahim Gibra yang diunggah ke laman lefo.id. Data kemudian dianalisis dengan cara menginterpretasikan puisi "Ramadan Kali Ini” melalui (1) pembacaan heuristik dan pembacaan hermeneutik; (2) pendeskripsian ketidaklangsungan ekspresi; (3) penentuan matriks, model, dan varian; (4) pendeskripsian hipogram puisi "Ramadan Kali Ini"; dan (5) penyimpulan data.

\section{HASIL DAN PEMBAHASAN}

Berikut ini adalah puisi "Ramadan Kali Ini” karya Ibrahim Gibra.

\section{RAMADAN KALI INI}

wabah itu datang

kita menjadi dua

yang ke masjid

dan yang tak ke masjid

yang ke masjid adalah yang tawakal yang tak ke masjid adalah ikhtiar

dari masjid

dari rumah

sama-sama kita ingin masuk surga.

\section{Pembacaan Heuristik dan Pembacaan Hermeneutik}

Wabah (korona) datang. Penyebarannya tergolong cepat. Pasien yang teridentifikasi postif jumlahnya semakin bertambah dari hari ke hari. Ada pasien yang sembuh ada pasien yang meninggal. Rumah sakit penuh, tak cukup ruang pagi pasien yang datang berobat. Pemerintah akhirnya mengeluarkan peraturan pembatasan sosial berskala besar. Kegiatan yang mengumpulkan banyak orang, termasuk beribadah di masjid, dilarang. Muncullah Peraturan Pemerintah No. 21 Tahun 2021 tentang Pembatasan Sosial Berskala Besar dalam Rangka Percepatan Penanganan Corona Virus Disease 2019 (Menteri Hukum dan Hak Asasi Manusia, 2020). 
Pandemi yang mulai berjangkit di Indonesia pada Maret 2020 tersebut terus berlanjut dan tidak menunjukkan tandatanda akan segera mereda hingga umat muslim memasuki bulan Ramadan. Sebagai akibatnya, Peraturan Pemerintah No. 21 Tahun 2021 itu pun menimbulkan pro dan kontra. Ada yang tetap pergi ke masjid, bertawakal bahwa segala sesuatau terjadi karena kehendak Tuhan. Ada yang memilih tetap di rumah, menganggap hal itu adalah ikhtiar mencegah penularan virus korona.

Umat Islam terbelah. Masjid-masjid dan musala-musala_yang pada hari-hari biasa ramai dikunjungi umat yang ingin tafakur dan beribadah salat wajib lima waktu dan salat tarwih secara berjamaah - terlihat lengang. Meskipun demikian, mereka (baik yang pro maupun yang kontra itu) samasama berkeinginan masuk surga.

Secara hermeneutik, puisi "Ramadan Kali Ini" mengisahkan perpecahan umat Islam: ada yang pro dan ada yang kontra terhadap peraturan pemerintah dalam menghadapi wabah korona. Dalam puisi tersebut, keterbelahan umat Islam itu tergambar dalam rangkaian kata yang ke masjid; yang tak ke masjid; dan menjadi dua.

Dalam puisinya, "Ramadan Kali Ini" itu, Gibra melukiskan kegamangan banyak orang ketika sesuatu yang tak kelihatan (covid-19) bisa mendatangkan kematian, semudah orang bernapas, di mana saja dan kapan saja, tak terkecuali pada saat orang melakukan ibadah. Ingin ke masjid, tetapi diminta tetap di rumah, padahal umat Islam percaya bahwa beribadah di masjid itu lebih utama daripada di rumah (terutama kaum laki-laki).

"Ramadan Kali Ini" menggiring pembaca merenungkan apa yang hilang (kebiasaan salat berjamaah di masjid juga mengahdiri pengajian) dan apa yang tetap tinggal. Puisi itu seolah mempertanyakan tingkat keimanan seseorang (muslim). Barangkali, Gibra tak bermaksud sejauh itu. Namun, Gibra menangkap fenomena di sekitarnya seperti yang selalu ia lakukan. Nalurinya sebagai penyair mendorongnya menulis sembilan baris puisi itu dengan kata-kata-tak sekadar simbolik, tetapi menyuarakan keterpecahan: yang tawakal dan yang ikhtiar. Keduanya wajib dimiliki dan diupayakan oleh mereka yang beriman. Masjid dan rumah menjadi pembeda yang tegas. Peristiwa itu hampir merata terjadi di Jakarta dan beberapa daerah di Indonesia.

Tiap kota besar, konon, selalu terbelah. Keterbelahan itu semakin menjadi-jadi sejak media sosial menjadi bagian dari gaya hidup. Hal itu tampak dalam puisi Gibra tersebut bahwa masyarakat mudah menjadi dua oleh apa saja. Perbedaan dan keragaman tidak lagi menjadi sesuatu yang indah. Sering kali perbedaan menjadi hal yang tak sederhana. Di negara ini, akhir-akhir ini, perbedaan sangat bisa memicu konflik dan memancing amarah. Agama seringkali dibawa-bawa dan dipelesetkan menjadi kedok: dalam iklan-iklan, dalam sloganslogan.

"Ramadan Kali Ini", sekali lagi, hadir dan menyadarkan kita bahwa kata dapat mengguncang kesadaran, mengingatkan akan keterbatasan mahluk bernama manusia. Kata-kata John F. Kennedy berikut ini menegaskan hal itu.

When power leads man toward arrogance, poetry reminds him of his limitations.

When power corrupts, poetry cleanses.

Subagio juga turut melantangkan kekuatan kata-kata melalui salah satu puisinya. Hanya dalam puisi, perbedaan bisa kembali indah: agama kembali murni. Kata bukanlah sarana untuk mengantarkan pengertian, ia bersifat 
netral (Lampan, 2014). Itu kredo Sutardji Calzoum Bahri tentang kata.

Akan tetapi, seperti telah dijelaskan di awal tulisan ini, adanya proses simbolik yang diikuti oleh perangkat pembentuk makna yang ampuh: tafsir, menjadikan puisi "Ramadan Kali Ini” peram di kepala. Simbol masjid, rumah, ramadan, tawakal, ikhtiar, dan surga terajut dan terbentuklah persepsi. Agama dan wabah dipertemukan. Kita bisa jadi akan menerjemahkannya sebagai perlambang iman, bisa berupa keyakinan yang teguh, dan apa pun opsi yang dipilih. Masjid melambangkan kemuliaan dan keutamaan: memakmurkan rumah Tuhan berhadapan dengan ikhtiar melawan wabah: beribadah di rumah. Keduanya sama-sama dirawikan dalam hadis.

\section{Ketidaklangsungan ekspresi}

Dalam puisi "Ramadan Kali Ini" tidak terjadi penggantian arti dan penyimpangan arti. Ketidaklansungan ekpresi yang terjadi hanyalah penciptaan arti. Hal itu disebabkan Gibra menggunakan bahasa sehari-hari, sesuai dengan pendapat Riffaterre bahwa puisi juga dapat menggunakan kata dan struktur bahasa seperti bahasa sehari-hari. Alternatif itu terus berkembang, bolak-balik bergantung pada evolusi selera dan konsep estetik ((Riffaterre, 1978).

Penciptaan arti dalam "Ramadan Kali Ini" terlihat pada keseimbangan (simitri) larik-larik berikut.

yang ke masjid

dan yang tak ke masjid

dan

\section{dari masjid}

dari rumah

Gibra mengembalikan fungsi sastra sebagai medium ekspresi individual meskipun ada kalangan elitis yang percaya bahwa sastra berfungsi sebagai agen perubahan sosial. Hal itu membuktikan bahwa, di samping sebagai pencatat yang rajin, Gibra juga sebagai pengamat yang peka. Catatan itu mendorongnya secara naluriah untuk mengungkap fenomena dan menangkarkannya dalam kata-kata, seperti yang dikatakan Freud tentang puisi: ungkapan yang terbentuk dari dorongandorongan naluri. Dalam puisi "Ramadan Kali Ini" inilah kegelisahan Gibra pada umat Islam yang terbelah itu tampak.

\section{Matriks, Model, dan Varian}

Matriks dalam dalam puisi "Ramadan Kali Ini" adalah adanya pro dan kontra dalam menghadapi bulan Ramadan saat wabah Covid-19 belum menunjukkan tandatanda akan segera berakhir, bahkan korban semakin bertambah. Model dalam puisi "Ramadan Kali Ini" adalah wabah dan bulan Ramadan. Sementara itu, varian-varian dalam "Ramadan Kali Ini" adalah sebagai berikut.

Pertama, wabah korona mulai menyebar, terus berlanjut sampai bulan Ramadan sehingga kebiasaan umat Islam beribadah di masjid menjadi berubah. Peraturan pemerintah tentang pembatasan kegiatan yang menyebabkan kerumunan, dalam hal ini salat tarawih dan salat Jumat, telah memecah belah umat: ada yang setuju dan tidak sedikit pula yang menolak. Ada kegamangan dalam menyikapi wabah. Tawakal dan ikhtiar diperdebatkan. Ujung dari perdebatan itu berakhir pada keinginan kedua pihak yang terpecah: sama-sama ingin masuk surga, seperti yang tampak pada bait pertama dan bait terakhir puisi "Ramadan Kali Ini” berikut ini.

wabah itu datang

kita menjadi dua

dari masjid

dari rumah

sama-sama kita ingin masuk surga. 
Dalam puisi Gibra tersebut ada rumah, masjid, dan surga yang melantangkan teks menjadi sesuatu yang menggetarkan. Masjid bersifat komunal dan akrab. Rumah terasa personal dan privat. Surga menjadi motif di balik itu semua.

Kata memeluk dalam frasa memeluk agama mendaraskan makna kerelaan dan kepasrahan untuk percaya kepada apa yang benar-benar diyakini dan diikutinya dengan keimanan yang kafah.

\section{Hipogram}

Hipogram puisi "Ramadan Kali Ini" adalah perpecahan umat Islam. Perpecahan ini berupa perbedaan pendapat - setuju dan tidak setuju-terhadap aturan penjarakan sosial yang diterapkan pemerintah dalam mencegah penularan virus Covid-19.

\section{PENUTUP}

Pada bagian pendahuluan telah dipaparkan bahwa bahasa puisi berbeda dengan bahasa sains. Riffaterre lalu menegaskan puisi adalah aktifitas bahasa yang berbeda dengan bahasa sehari-hari. Teori Semiotika Riffaterre menjadi tepat digunakan untuk menganalisis puisi Ramadan Kali Ini dengan merujuk kepada hipogram puisi yang dianalisis, terutama peristiwa yang melatarbelakangi atau memberi ilham kepada pengarang dalam berkarya. Dalam puisi ini, wabah virus Covid-19 atau koronalah yang membuat pengarang mengendapkan kegelisahaan terhadap bangsanya yang terbelah dan akhirnya menciptakan puisi ini.

Teori Semiotika Riffaterre juga menjadikan pemaknaan puisi menjadi lebih mudah melalui empat tahapan pembacaan dalam memproduksi makna puisi. Meskipun puisi Ramadan Kali Ini menggunakan bahasa sehari-hari, hal itu tidak bertentangan dengan pendapat Riffaterre yang mengatakan bahwa puisi juga dapat menggunakan kata dan struktur bahasa seperti bahasa sehari-hari. Alternatif itu terus berkembang, bolak-balik bergantung pada evolusi selera dan konsep estetik

\section{DAFTAR PUSTAKA}

Adudu, H. H., \& Husain, D. (2019). "Semiotic Analysis in William Blake Poems". Dalam British (Jurnal Bahasa dan Sastra Inggris), 8(1), 39. https://doi.org/10.31314/british.8.1.3954.2019

Bujono, B. (2020). "Ia yang tak Menkhianati Puisi". Dalam Tempo, Edisi Agustus.

Camus, A. (1948). The Plague. Random House, Inc. http://dactylreview.com/2013/05/02/the -plague-by-albert-camus/

Gibra, I. (2019). Karang Menghimpun Bayi Kerapu (I). Jual Buku Sastra.

Huri, R. M., Hayati, Y., \& Nst, M. I. (2017). Analisis Semiotika Riffaterre Dalam Puisi Dongeng Marsinah Karya Sapardi Djoko Damono. Bahasa Dan Sastra, 5(1), 52-66.

Lampan, K. L. (2014). 80 Sajak Puncak dalam Sejarah Sastra Indonesia. Narasi.

Menteri Hukum dan Hak Asasi Manusia. (2020). Peraturan Pemerintah No.21 Tahun 2020 tentang Pembatasan Berskala Besar dalam Rangka Percepatan Penanganan Corona Virus Disease 2019.

Mohamad, G. (2020). Kata dan Pengalaman (T. Setiadi (ed.); I). Penerbit Circa.

Pradopo, R. D. (1999). "Semiotika: Teori, Metode, dan Penerapannya dalam 
Pemaknaan Sastra". Dalam Jurnal Humaniora.

Riffaterre, M. (1978). Semiotic of Poetry (T. A. Sebeok (ed.); II). Indiana University Press.

Saramago, J. (1997). Blindness. The Harvill Press.

Sneineh, M. A. (2020). Plague and Poetry: How Middle East Authors Have Written about Disease Middle East Eye.https://www.middleeasteye.net/disc over/coronavirus-middle-east-covid-19writer-plague-poet-book 
Telaga Bahasa Vol.8, No.2, Oktober 2020 